\title{
New weldability model based on the welding parameters and hardness profile
}

\author{
Marius BODEA ${ }^{1, \text { a }}$ \\ ${ }^{1}$ Faculty of Materials and Environmental Engineering, Technical University of Cluj, B-dul Muncii \\ 103-105, 400641, Romania \\ ambodea@stm.utcluj.ro
}

Keywords: Weldability, Maximum hardness, HAZ

\begin{abstract}
The weldability of the steels represents a problem of great interest in order to achieve welded structures that satisfy the high requirements on quality, imposed by the nowadays applications. In this paper has been proposed a more advanced model that has considered more factors of weldability influence, thus allowing a more detailed analysis based on the main welding process variables.
\end{abstract}

\section{Introduction}

Weldability is a general technological property commonly used in engineering, but very difficult to be defined and quantified in an exact manner. The American Welding Society has defined the weldability as being: "The capacity of a metal to be welded under the fabrication conditions imposed with a specific suitability designed structure and to perform satisfactorily in service” [1]. According to DIN 8528, Part 1 the weldability is seen as the output of the interaction of three main group factors, given in Table 1 [2].

Table 1. The weldability's factors of influence.

\begin{tabular}{|c|c|c|}
\hline $\begin{array}{l}\text { MATERIAL } \\
\text { WELDING SUITABILITY }\end{array}$ & $\begin{array}{l}\text { MANUFACTURE } \\
\text { WELDING POSSIBILITY }\end{array}$ & $\begin{array}{l}\text { DESIGN } \\
\text { WELDING SAFETY }\end{array}$ \\
\hline $\begin{array}{l}\text { - Chemical composition } \\
\text { - Metallurgical properties } \\
\text { - Physical properties }\end{array}$ & $\begin{array}{l}\text { - Welding preparation } \\
\text { - Welding execution } \\
\text { - Heat treatments } \\
\end{array}$ & $\begin{array}{l}\text { - Design } \\
\text { - Stress condition }\end{array}$ \\
\hline $\begin{array}{l}\text { - Tendency to hardening } \\
\text { - Tendency to ageing } \\
\text { - Tendency to hot cracking } \\
\text { - Weld pool behaviour } \\
\text { - Segregations } \\
\text { - Inclusions } \\
\text { - Grain size } \\
\text { - Anisotropy } \\
\text { - Expansion coefficient } \\
\text { - Thermal conductivity } \\
\text { - Melting point } \\
\text { - Mechanical properties }\end{array}$ & $\begin{array}{l}\text { - Welding technology } \\
\text { - Groove shape } \\
\text { - Preheating } \\
\text { - Susceptibility to cracking } \\
\text { - Heat input control } \\
\text { - Welding position } \\
\text { - Welding sequence } \\
\text { - Weld penetration } \\
\text { - Pool shape } \\
\text { - Post weld heat treatment } \\
\text { - Grinding } \\
\text { - Pickling }\end{array}$ & $\begin{array}{l}\text { - Material thickness } \\
\text { - Notch effect } \\
\text { - Stiffness differences } \\
\text { - Joint geometry and } \\
\text { displacement } \\
\text { - Type and level of strains } \\
\text { - Temperature } \\
\text { - Corrosion } \\
\text { - Loads and stress } \\
\text { - distribution } \\
\text { - Weld bead shape }\end{array}$ \\
\hline
\end{tabular}


From this definition it can observed that one should consider many factors in order to assess the weldability, like: filler and parent material properties, chemical compositions, metallurgical compatibility between them, metallic structure design, service conditions (load, temperature, environmental corrosion), welding parameters and manufacturing technology, but also the structure resistance to the service degradation in time. The welded structure performance is direct related to these factors that are controlling the weld mechanical properties, the nature and size of the imperfections produced in the weld and heat affected zone (HAZ), respectively the behaviour and life span of the welded structure in service.

In the literature can be found several methods for weldability assessment, based on the indirect methods, like: carbon equivalent formulae [3], peak hardness in HAZ [3, 4], or susceptibility cracking in HAZ due to hardening effect [4-6]. None of these methods have considered the simultaneous influence of different parameters in the proposed mathematical models, like it happens in the real phenomena. As a consequence, the validity of each method is limited priory, because there are many significant factors of influence, that have been ignored from the very beginning. In the paper it has been proposed a new weldability model, that takes into account the influence of the main factors, like: $t_{8-5}$ cooling time, carbon equivalent, material thickness, parent material hardness and its microstructural features, respectively the mean grain diameter size. Thereby, the weldability estimated by this model can make a difference for the same materials, with the same chemical composition $\left(\mathrm{C}_{\text {ech }}\right)$, but having different microstructural features or welded with different technologies or welding parameters.

In this model, the weldability has been expressed by a single number between 0 and 1 , the latter being assumed for an ideal weldability situation. Between the two extreme limits, there are unlimited intermediates values, corresponding for the real welding situations, the transitions between them, being made continuously. The weldability number calculated by the model proposed in the paper, can be used further in the estimating preheat temperature or for predicting mechanical properties of the welded joints.

\section{Carbon Equivalent Formulae}

In welding applications, carbon has a strong effect on the steel's weldability, reducing the ductility and material toughness. In order to assure high strength required in the many welded applications, new materials with very low carbon content has been developed lately, like the TMCP or HTUFF steels [7]. In the same time, beside the carbon equivalent index, the section size of the welded metallic structure plays a very important role, being related to the cooling rate, material properties and heat input. Hence, the carbon equivalent formula $\mathrm{Ceq}(\mathrm{s})$ compensated from the material thickness perspective of view, is given in the eq (1), where the thickness material $s$ is given in $\mathrm{mm}$, [7]. For the carbon equivalent relation Ceq we have considered a Japanese formula that is evaluating the hardening of the welds, given in eq(2), [9].

$$
\begin{aligned}
& C e q(s)=C e q+0.00425 \cdot s \\
& C e q=C+\frac{S i}{24}+\frac{M n}{6}+\frac{N i}{40}+\frac{C r}{5}+\frac{M o}{4}+\frac{V}{14}
\end{aligned}
$$

The compensated carbon equivalent formula is used in the weldability assessment as a direct parameter of influence, but also in the estimating hardness in HAZ, accordingly to the heat input,

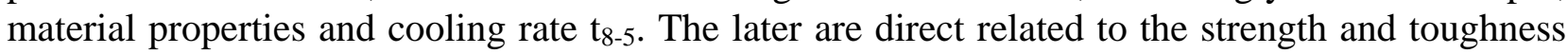
in the HAZ and deposited metal. 


\section{Cooling Time $\mathbf{t}_{8-5}$ and Hardness}

The cooling time between 800 and $500^{\circ} \mathrm{C}$ has a very important significance over the HAZ maximum hardness and cracking susceptibility in this area [3 - 6]. For this reason, the weldability models based on the cooling time are frequently used in practice. There are two opposite effects related to the thermal history of the welding cycle. A low heat input lead to excessive hardness and increased risk of cold cracking in the HAZ or even in the weld, accordingly to the specific properties of the parent and filler materials, but also on the welding technology and stress distributions. On the other part, a heat input too high, lead to low mechanical properties due to grain coarsening effect in HAZ, but also toughness depreciation or other inconveniences, related to the welding quality and performance.

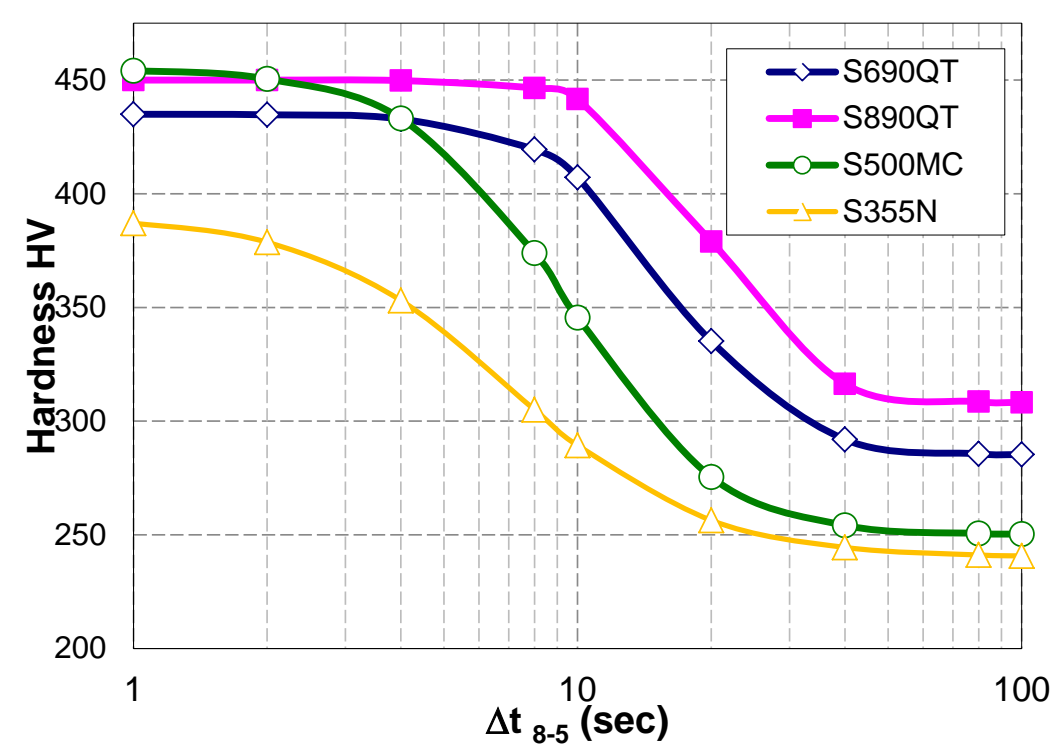

Fig. 1. HAZ hardening for different materials as a function of cooling time $t_{8-5}$ after welding, calculated after [8].

From the Fig. 1, it can be observed the sigmoid evolution of the hardness in the HAZ based on the cooling time $t_{8-5}$ for different steels used commonly in welded applications. The weldability can be related to this kind of evolution, but with considering other parameters of influence as well. The hardenability of material in the HAZ and also cracking susceptibility depends directly on the

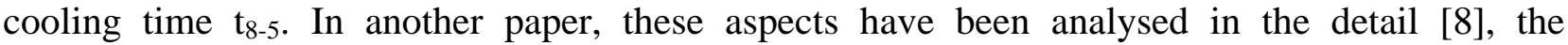
microstructural characteristics being essential for the most properties envisaged in welded applications. However, for the simplicity of the model, it has been considered only the cooling time $t_{8-5}$ as essential variable from the thermal cycle related variables, the microstructure being considered as an output of all the factors involved from this point of view.

Based on the data extracted from the Fig. 1, it has been expressed the hardness HV vs. cooling time using the logistic functions with five parameters (5PL). The logistic function has the expression given in the eq(3), and the vector parameters $\mathrm{p}[\mathrm{a}, \mathrm{b}, \mathrm{c}, \mathrm{d}, \mathrm{e}]$ has been given for each kind of material in the Table 2. 


$$
F(x ; p)=a+\frac{d-a}{\left[1+\left(\frac{x}{c}\right)^{b}\right]^{e}}
$$

Table 2. Parameter vector for the 5PL functions used for HV hardness modelling.

\begin{tabular}{|c|c|c|c|c|c|c|}
\hline \multirow{2}{*}{$\begin{array}{l}\text { No. } \\
\text { crt. }\end{array}$} & \multirow[b]{2}{*}{$\begin{array}{c}\text { Parent } \\
\text { material }\end{array}$} & \multicolumn{5}{|c|}{ Vector parameters p[a,b,c,d,e] } \\
\hline & & $\begin{array}{c}\text { a } \\
\text { Minimum } \\
\text { horizontal } \\
\text { asymptote }\end{array}$ & $\begin{array}{c}\mathrm{b} \\
\text { Hill } \\
\text { slope }\end{array}$ & $\begin{array}{c}\text { c } \\
\text { Cooling speed } \\
\text { for inflection } \\
\text { point }\end{array}$ & $\begin{array}{c}\text { d } \\
\text { Maximum } \\
\text { horizontal } \\
\text { asymptote }\end{array}$ & $\begin{array}{c}\text { e } \\
\text { Asymmetry } \\
\text { factor }\end{array}$ \\
\hline 1. & S500MC & 250 & 2.4 & 10.5 & 455 & 1.2 \\
\hline 2. & S355N & 240 & 2 & 7 & 390 & 1 \\
\hline 3. & S690QT & 285 & 3 & 17.5 & 435 & 1.2 \\
\hline 4. & S890QT & 308 & 4 & 20 & 450 & 1 \\
\hline
\end{tabular}

The maximum hardness in the HAZ can constitute a parameter for weldability assessment. As can be seen in the Fig. 2, the maximum HAZ hardness increases as the Ceq increases, between them existing a linear correlation, given in the eq(4), [9].

$$
\operatorname{Hmax}=(666 C e q+40) \pm 40
$$

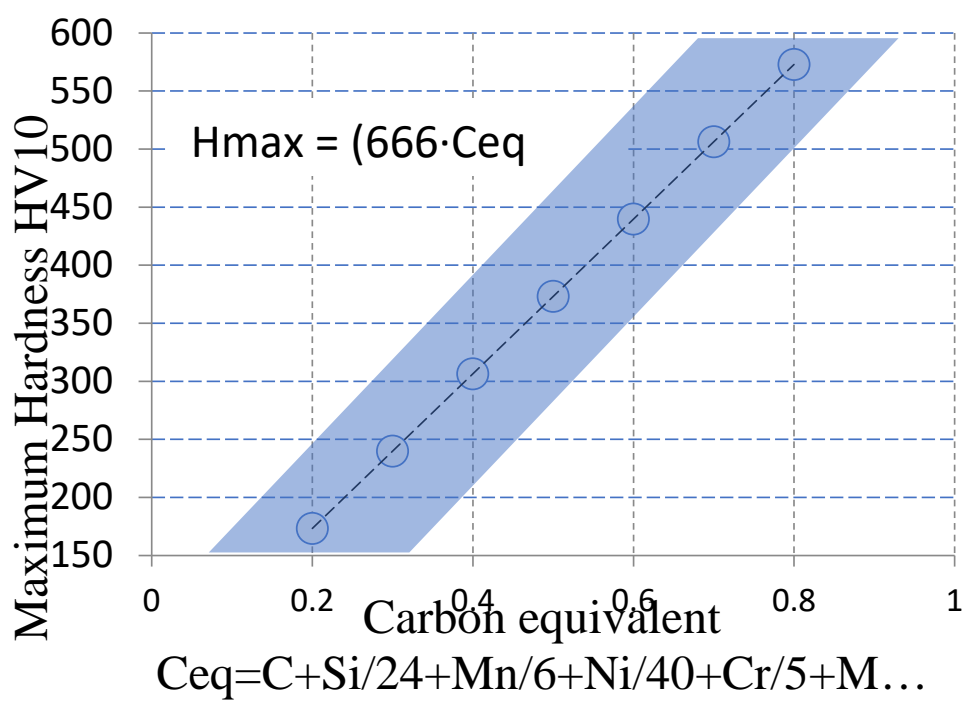

Fig. 2. Maximum HAZ hardness vs. Ceq of 20-mm thick mild steel, calculated after [9]. 


\section{Microstructure}

The thermal welding cycle plays a key role in the microstructure characteristics in the HAZ and deposited metal. Different microstructural constituents can result, under different cooling conditions, accordingly to the chemical composition and former austenite grain size. Inclusions or inhomogeneity present in the parent material can also contribute significantly to the new product phases or constituents, resulted after austenite transformations during cooling.

Complex microstructures are formed, containing mixtures of upper bainite, lower bainite, granular bainite, ferrite laths, martensite, martensitic/austenitic (M/A) islands. For instance, in many rolled steels, bands reach in $\mathrm{C}$ and $\mathrm{Mn}$ can be found. $\mathrm{Mn}$ is a strong austenitizer element, decreasing the austenite decomposition temperature. If cooling conditions lead to an undercooling phenomenon, is very likely that in such cases the microstructure will be dominated by the bainite and martensite microstructural constituents. High cooling rates, very often meet in practice associated with low heat inputs, are reducing the time required by the diffusion-controlled processes. As result, the microstructure will be formed predominantly by martensitic and lower bainitic structures. It's very important to control the austenite grain size growing effect during heating cycle, because is in direct relation with the material hardenability.

Non-metallic inclusions play also a very important role in the nucleation process and resulting microstructure in the weld and HAZ, contributing to a grain refinement process. From these facts, it can be concluded that is essential for the weldability mathematic model to consider the influence of the parent initial microstructure, through the mean grain size of the ferritic matrix.

\section{Weldability Mathematic Model}

As has been stated before, the model is considering a continuously evolution of the weldability, that is expressed by a single number comprised between 0 and 1 , existing a direct proportional variance between the weldability and its associated number.

As result, 0 means absolute no weldability, while 1 means an ideal weldability. The weldability variation must present saturation effect towards to the both limits. For this purpose, it has been considered a 5PL function that can be shaped very easily using a 5-parameter vector. Those parameters have been designed in order to account the influence of the main weldability factors, like: the $t_{8-5}$ cooling time, carbon equivalent, material thickness, parent material hardness and the mean grain diameter size for the parent material. The function for the weldability proposed model, has the following equation:

$$
W N=a+\frac{d-a}{\left[1+\left(\frac{C e q}{c}\right)^{b}\right]^{e}}
$$

where:

$\mathrm{WN}=$ weldability number $(0-1)$.

$\mathrm{a}=$ minimum horizontal asymptote $(\mathrm{a}=0)$. Minimum theoretical weldability.

$\mathrm{b}=$ Hill slope, is expressing how fast the weldability changes around the inflection point.

$\mathrm{c}=$ weldability speed related to Ceq. Locates the inflection point.

$\mathrm{d}=$ maximum horizontal asymptote $(\mathrm{d}=1)$. Maximum theoretical weldability.

$\mathrm{e}=$ asymmetry factor for the weldability curve. $(\mathrm{e}=1$, weldability curve is symmetrical in relation to the inflection point). 
Because of the very numerous factors that affect the weldability, instead a single weldability curve should be considered two curves, that are determining a weldability band, very likely to a hardenability band. Thus, for a specific material and welding conditions, the weldability falls within the weldability band illustrated in the Fig. 3.

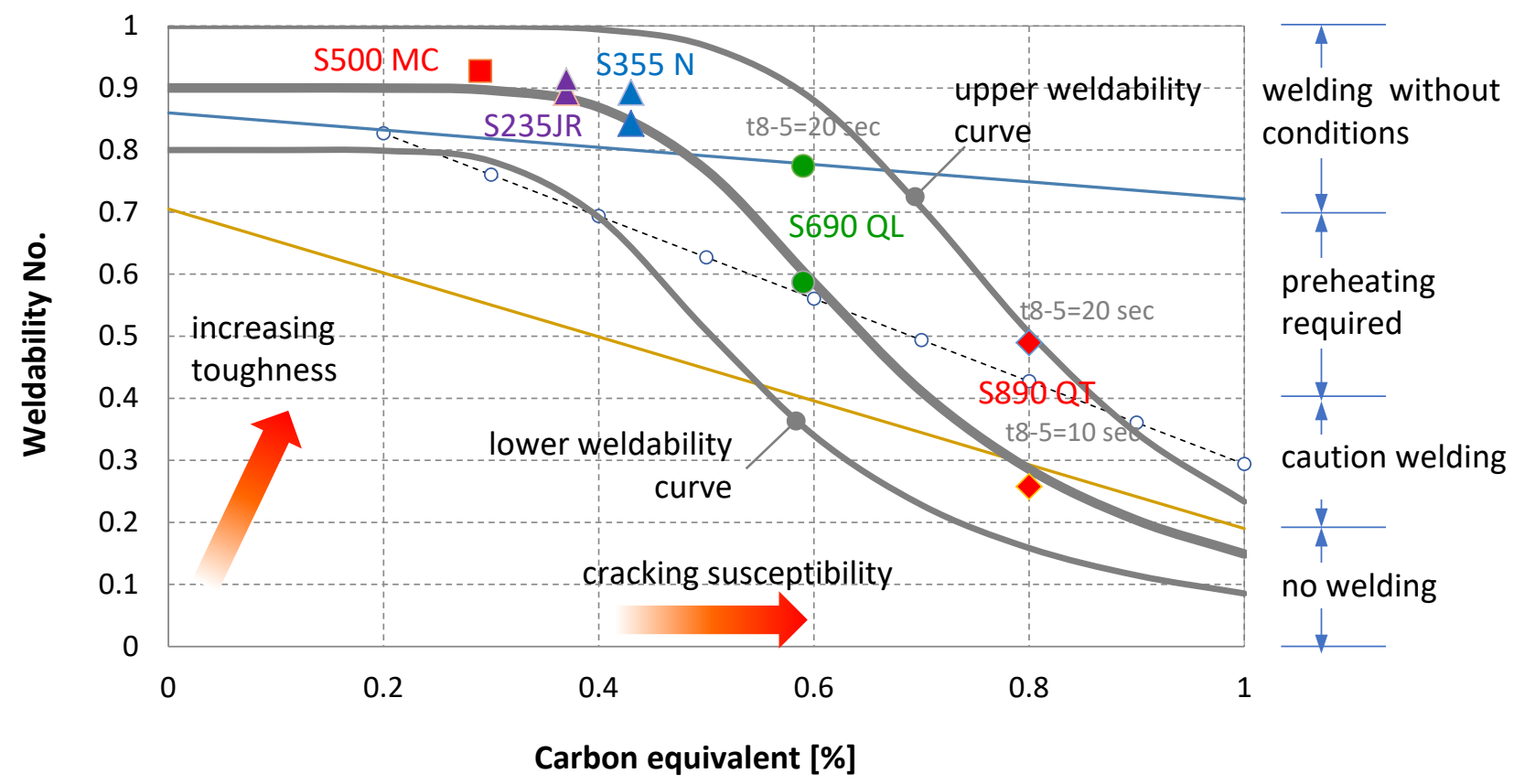

Fig. 3. Weldability band for steels fusion welding processes.

For the upper and lower weldability curves, the parameters vector $p$ is as it follows:

Upper weldability curve Lower weldability curve

$a=0 ; b=8 ; c=0.7 ; d=1 ; e=0.5$ $\mathrm{a}=0 ; \mathrm{b}=7 ; \mathrm{c}=0.45 ; \mathrm{d}=0.8 ; \mathrm{e}=0.4$

The weldability can be improved if the grain size of the parent material is reduced. This effect has been considered by the parameter vector $\mathrm{c}$, that determine the inflection point position. Lower values for $d_{F}$ which stand for the ferritic mean grain size, is improving the weldability curve that is shifted to left or to right, accordingly to the eq.(6), for the $c$ parameter, Fig. 4 and Fig. 5, where $\mu$ represent the optimum $t_{8-5}$ cooling time and $\sigma$ is the standard deviation.

$$
c=c_{\max } \cdot \exp \left[-0.5 \cdot\left(\frac{t 85-\mu}{\sigma}\right)^{2}\right]+0.1 \cdot \frac{1}{\sqrt{d F}}
$$




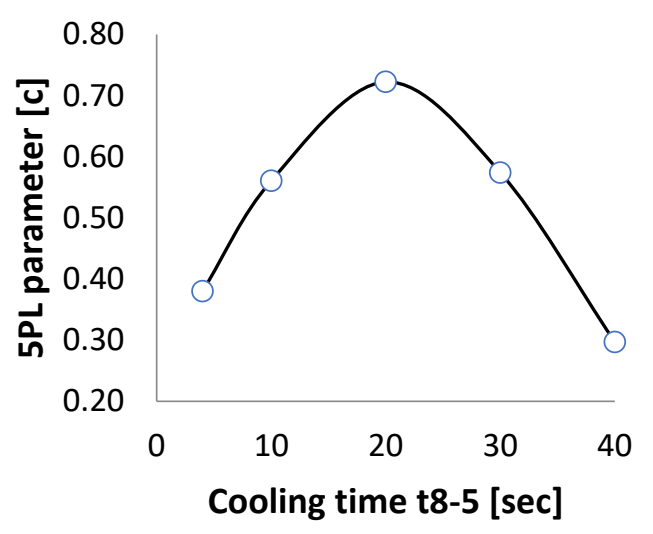

a) Parameter c vs. cooling time $t_{8-5}$ and mean diameter grain size $(\mathrm{dF})$

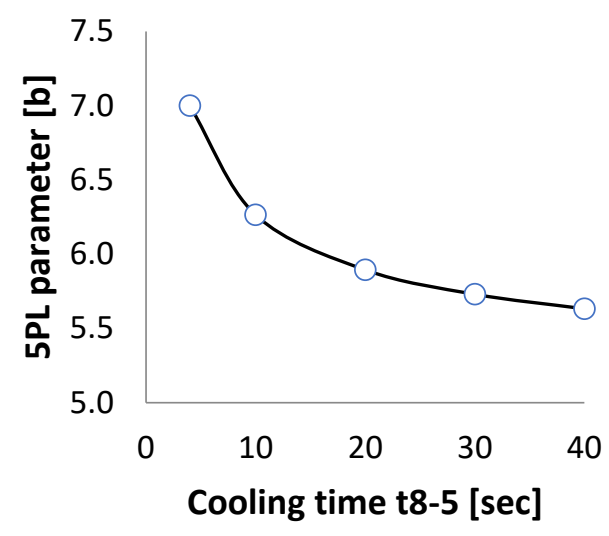

b) Parameter b vs. cooling time $t_{8-5}$

Fig. 4. Parameter vector $\mathrm{c}$ and $\mathrm{b}$ for the 5PL weldability function.

The Hill slope given by the parameter $b$ of the 5PL weldability curve is controlled by the cooling time $t_{8-5}$. As can be seen in the Fig. 1, for each material can be determined an optimum interval for the t8-5 $_{5}$ cooling time, if we consider the maximum HV hardness in the HAZ. Shorter times will lead to hardening effect in the HAZ, while longer times will lead to insufficient weld toughness due to coarsening effect in the HAZ.

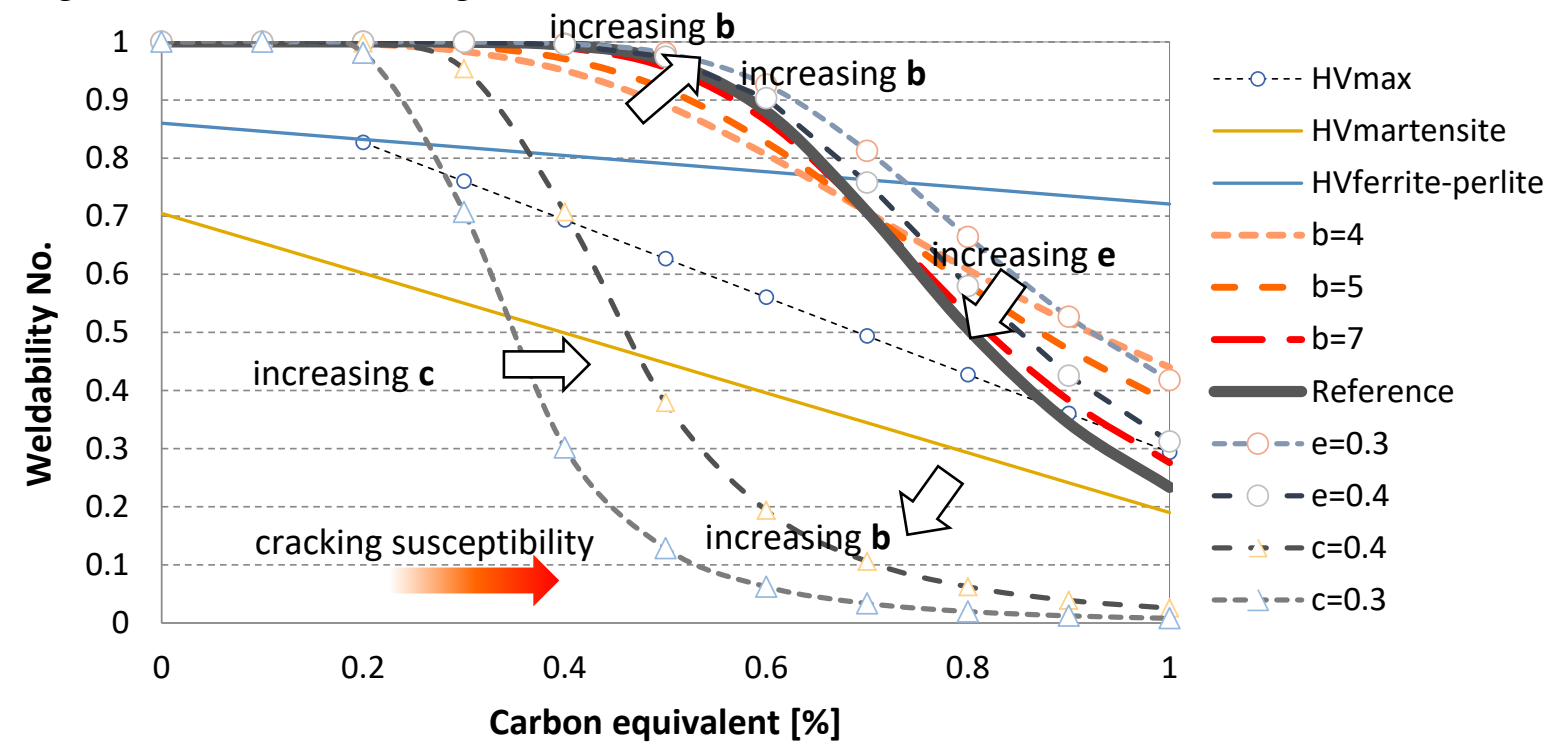

Fig. 5. The shape of the 5PL weldability curve vs. parameter vector p[a,b,c,d,e], the reference curve has $\mathrm{p}[\mathrm{a}=0, \mathrm{~b}=5.6, \mathrm{c}=0.5, \mathrm{~d}=1, \mathrm{e}=0.5]$.

By modifying the Hill slope ( $b$ parameter), we can adjust the weldability curve accordingly to the $t_{8-5}$ cooling time, Fig. 5. The parameter $b$ is calculated using the eq. (7) and illustrated in the Fig. 4. 


$$
b=5+\frac{4}{\sqrt{t_{8-5}}}
$$

The asymmetry factor $e$ has been determined based on the hardness $\mathrm{HV}$ of the parent material influence, that is related to the Ceq, carbon equivalent formulae. The asymmetry factor is stretching the weldability curve, accordingly to the $e$ value, calculated with eq.(8), Fig. 5.

$$
e=0.4+0,2 \cdot \mathrm{Ceq}
$$

\begin{tabular}{|c|c|c|c|c|}
\hline Observation & \multicolumn{2}{|c|}{$\begin{array}{l}\text { Conventional weldability classification } \\
\text { based on the Ceq }\end{array}$} & \multicolumn{2}{|c|}{$\begin{array}{l}\text { New weldability classification based on } \\
\text { the 5PL function }\end{array}$} \\
\hline $\begin{array}{l}\text { Excellent } \\
\text { weldability }\end{array}$ & Ceq < 0,40\% & $\begin{array}{l}\text { No preheating } \\
\text { required }\end{array}$ & $\mathrm{WN}>0.8$ & $\begin{array}{l}\text { Faster cooling is possible } \\
\text { in order to achieve a good } \\
\text { balance between } \\
\text { toughness and strength. }\end{array}$ \\
\hline \multirow[t]{2}{*}{$\begin{array}{l}\text { Good } \\
\text { weldability }\end{array}$} & \multirow{2}{*}{$\begin{array}{c}0,40 \%<\text { Ceq }< \\
0,50 \%\end{array}$} & \multirow{2}{*}{$\begin{array}{l}\text { Preheating of } 200 \\
\text { to } 250^{\circ} \mathrm{C} \text { for wall } \\
\text { thickness }>25 \mathrm{~mm}\end{array}$} & $0.7<\mathrm{WN}<0.8$ & \multirow{2}{*}{$\begin{array}{l}\text { No preheat required } \\
\text { (WN }>0.7 \text { ), but very } \\
\text { narrow welding range } \\
\text { parameters available. }\end{array}$} \\
\hline & & & $0.6<\mathrm{WN}<0.7$ & \\
\hline $\begin{array}{l}\text { Possible } \\
\text { weldability }\end{array}$ & $\begin{array}{c}0,50 \%<\text { Ceq }< \\
0,60 \%\end{array}$ & $\begin{array}{l}\text { Preheating of } 250 \\
\text { to } 300{ }^{\circ} \mathrm{C} \text { for wall } \\
\text { thickness }>15 \mathrm{~mm}\end{array}$ & $0.4<\mathrm{WN}<0.6$ & $\begin{array}{l}\text { Preheat required, } \\
\text { calculated accordingly to } \\
\text { DIN EN 1011-2:2001 }\end{array}$ \\
\hline $\begin{array}{l}\text { Poor } \\
\text { weldability }\end{array}$ & Ceq > 0,60 \% & $\begin{array}{l}\text { Preheating of } 300 \\
\text { to } 400{ }^{\circ} \mathrm{C} \text { for wall } \\
\text { thickness }>15 \mathrm{~mm}\end{array}$ & $0.2<\mathrm{WN}<0.4$ & $\begin{array}{l}\text { The welding can be } \\
\text { possible by selecting } \\
\text { proper welding } \\
\text { parameters and } \operatorname{Tp}\left({ }^{\circ} \mathrm{C}\right) \text {. }\end{array}$ \\
\hline $\begin{array}{l}\text { No } \\
\text { weldability }\end{array}$ & Ceq > 0,80 \% & No weldability & $\mathrm{WN}<0.2$ & $\begin{array}{l}\text { No weldability or very } \\
\text { poor weldability }\end{array}$ \\
\hline
\end{tabular}

Table 3. Weldability classification systems.

Beside the Ceq values, it can be made a new classification of the steels weldability based on the weldability number, calculated with the 5PL formula. Comparative to the conventional Ceq weldability classification, the weldability number is containing the influence of others main factors of influence for the steels weldability, allowing a more advanced analysis. With the new weldability model, for a given material with a particular Ceq, has been obtained a weldability range accordingly to the welding conditions, thus the weldability property being more precise evaluated. In the previous cases, when only one parameter was considered at a time, this was not being possible. For the very same material it could be used or obtained different $t_{8-5}$ cooling times, grain size diameters, heat treatment conditions, thickness or welding parameters, that can make a difference in material weldability. Finally, for $d$ parameter has been used the relation given in eq.(9), that determine a range of variation for this parameter between 1 and 0.8 for $0<\mathrm{Ceq} \leq 1 \%$ : 


$$
d=1-\frac{C e q^{2}}{5}
$$

In the Table 3, are presented comparatively the weldability classification in both systems, one based on the Ceq and the other one, on the 5PL weldability function. Also, for each case scenario are given the recommended measures for welding.

\section{Summary}

1. The steels weldability remains a problem of great interest, due to the higher requirements regarding the quality and performance of the welded structures.

2. The proposed model in this paper is evaluating more accurate the steel's weldability. In this model has been considered the influence of the main parameters: $t_{85}$ cooling time, carbon equivalent, material thickness, parent material hardness and the mean grain diameter size of the parent material.

3. The weldability is confined between two limits, from the ideal weldability characterized by $\mathrm{WN}=1$, to the hypothetical case with zero weldability $(\mathrm{WN}=0)$. The weldability is varying continuously between the two extremes limits, accordingly to the welding process parameters and materials properties.

4. One material can present different weldability values, according to welding parameters.

5. The shape of the 5PL weldability function can be easily adjusted accordingly to the parameter vector $\mathrm{p}[\mathrm{a}, \mathrm{b}, \mathrm{c}, \mathrm{d}, \mathrm{e}]$ that is set based on the main process variables.

6. The weldability number can be used further for preheat temperature calculus.

7. The model can be improved further by considering the influence of other factors, related to the welding process or material properties.

8. The influence of parameter vector $\mathrm{p}[\mathrm{b}, \mathrm{e}]$ over the $5 \mathrm{PL}$ shape weldability function is more important for steels with higher Ceq (Ceq>0.4). The steels with Ceq $<0.4 \%$ (or WN $>0.7$ ) can be welded with more flexible welding parameters, without affecting the weldability steel in a significant manner.

\section{References}

[1] L. Jeffus, Welding and Metal Fabrication, ISBN-13: 978-1-4180-1374-5, Delmar Cengage Learning, (2012) 780-781.

[2] Springer Handbook of Mechanical Engineering, Volume 10, Karl-Heinrich Grote,Erik K. Antonsson, ISBN: 978-3-540-49131-6, (2009) 3-4.

[3] Carbon Equivalent to Assess Hardenability of Steel and Prediction of HAZ Hardness Distribution, T. Kasuya, Y. Hashiba, Nippon Steel Technical Report No. 95 (2007).

[4] Kasuya, Tadashi, Nobutaka Yurioka, and Makoto Okumura. "Methods for predicting maximum hardness of heat-affected zone and selecting necessary preheat temperature for steel welding." Nippon Steel Technical Report (1995) 7-14.

[5] H. Suzuki, Revised Cold Cracking Parameter $\mathrm{P}_{\mathrm{HA}}$ and its Applications. Transactions of the Japan Welding Society, (1985) 40-49.

[6] N. Yurioka, Physical metallurgy of steel weldability. ISIJ international, (2001) 566-570. https://doi.org/10.2355/isijinternational.41.566 
[7] G.T. Murray, Handbook of Materials Selection for Engineering Applications, ISBN: 0-82479910-0, (1997) 135-136.

[8] M. Bodea, R. Mureşan, Computation of HAZ hardness for low alloyed welded steels using fiveparameter logistic function, doi:10.4028/www.scientific.net/SSP.216.103, Solid State Phenomena Vol. 216, (2014) 103-109. https://doi.org/10.4028/www.scientific.net/SSP.216.103

[9] Kobelco, The ABC's of Arc Welding and Inspection, Kobe Steel Ltd. (2015) 81-83, http://www.kobelco-welding.jp/education-center/abc/ABC_2007-01.html. 